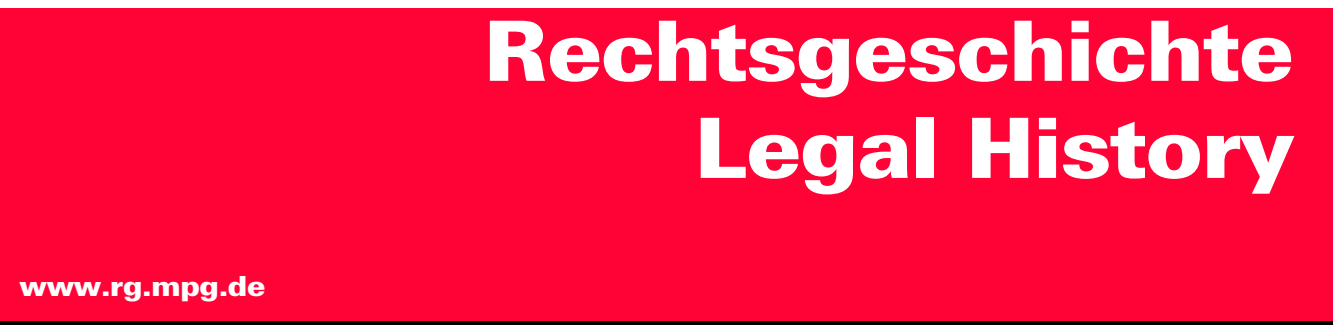

http://www.rg-rechtsgeschichte.de/rg27

Zitiervorschlag: Rechtsgeschichte - Legal History Rg 27 (2019)

$\operatorname{Rg} 272019$

$322-324$

http://dx.doi.org/10.12946/rg27/322-324

\title{
Victoria Barnes*
}

\section{Big Business}

* Max Planck Institute for European Legal History, Frankfurt am Main, barnes@rg.mpg.de 


\section{Victoria Barnes Big Business*}

This collection edited by Dave De ruysscher, Albrecht Cordes, Serge Dauchy and Heikki Pihlajamäki considers what size or varieties of business were considered to be the best. The answer to this question depends on the time period under examination, and it also differs between jurisdictions. The chapters in the collection take a broad approach as they collectively cover a long time span and have a wide geographical spread. They consider examples from the Middle Ages, the early modern period and the $19^{\text {th }}$ century. The places examined here are now in the jurisdictions of Germany, Italy, Belgium, Spain and England. As a whole, the chapters address some of the tension between the perceived advantages and disadvantages of big business against the small and medium enterprises (SMEs) and also the limited liability corporation in comparison to the unlimited liability partnership form. The edited collection takes a deliberately integrative approach, as it combines concepts and ideas from legal studies with those of economic history, business studies and comparative political analysis.

This is a pan-European take on a discussion that has traditionally been at the centre of American scholarship in the field of business and economics. In the 1960s, Alfred Chandler theorised about the growth of big business. In his narrative, management was key to understanding economic growth. Markets, he argued, were not controlled by invisible forces of supply and demand but by the visible hand of managers. Managers, through improved manufacturing processes and technological innovation, could increase or improve supply. With marketing and advertising techniques, they could control the demand for their goods. Managers could only strategise, plan and coordinate the market functions when they had subordinates who relieved them of the burden of the day-today activities of running the company. A manage- rial hierarchy, therefore, became the centre of academic interest. It was seen as the benchmark of an efficient large-scale enterprise. In other words, the bigger the company, the better it was.

This sort of thinking no longer dominates the historical study of business. There is no longer much interest in identifying the presence or absence of a managerial hierarchy in big business. Economists and those in business and management studies have also questioned some of these theoretical assumptions; they do not believe that »bigger is better«. Much attention is now paid to issues associated with entrepreneurship, innovation and strategy as well as managerial structure. This edited collection follows this new approach, which reconsiders some of the basic assumptions which have been made in the past. Annamaria Monti's chapter on organisational form, size and governance in Italian companies in the $19^{\text {th }}$ century is exceptionally good in this regard. By sketching out the coming of limited liability, Monti's chapter provides a strong link between the present approaches and old debates. Early Italian business history, led by Franco Amatori, keenly adopted Chandler's research, his theoretical framework and his ideas. Italian business and economic history has been enriched by these efforts. Monti's chapter is an effective bridge between new and old thinking in economic and legal history.

When the chapters in this collection are taken as a whole, they add much to the perspective that the corporation may not be the »best« form of business organisation. The contributions of Luisa Brunori, Bart Lambert and Dave De ruysscher are particularly successful in producing these conclusions. Brunori recreates the debate in religious discourse and commercial law about partners and partnerships using the work of the late scholastics. Lambert shows that enterprises based in medieval Italian cities operating in Bruges varied in size and 
that this mix benefited the communities. De ruysscher rehabilitates the partnership, claiming that it had advantages in $19^{\text {th }}$-century Antwerp.

The eight chapters in this collection show that there were various ways of organising commerce, trade and business groups. It attempts to drive the future research agenda and adds weight to the two main hypotheses about the nature of the relationship between law and business. Its two major claims concern law and practice: the chapters show that (1) legal doctrine was irrelevant to business practice and (2) merchants co-operated with each other and with legal professionals in devising legal structures. The edited collection, therefore, also provides a strong way of linking economic and business concepts to legal concepts. This is a difficult task - especially given the differing sizes of the economies, populations, industries, the huge variation in available transport and communication means and in the levels of regional integration in the periods and topics covered by the eight different chapters. This means that what is a large-scale company in one area at one time will not be the same as in another. To combat this comparative problem, the chapters focus on common legal understandings of limited liability, mostly through the lens of legal personhood. They use features of large and small companies to examine these legal concepts. Despite the legal focus, there is much for the economic and business historian here as well. Risk, investors, shields and protection are also common themes.

The chapter on England and the East India Company written by Stefania Gialdroni notes the confusion in terminology in English law, economics and business. The terms now used to describe the organisational forms of limited liability $v$ unlimited liability or the corporation $v$ the partnership did not exist in the early modern period. The language of »big business « and SMEs similarly developed later and became common only in the $20^{\text {th }}$ century. The expression »joint stock company» in the $18^{\text {th }}$ and $19^{\text {th }}$ centuries encompassed all of these ideas. It could be a limited liability company; it could be an unlimited liability company; it could be used to describe a large-scale industrial firm or a small fledgling enterprise. Given the multiple meanings of these words, it is interesting to see how the authors using non-English legal languages translate their legal terms into a language that historically was indiscriminate and terminologically foggy.
Some of the phrasing here is curious and where it prompts question, there is explicit discussion of meanings. Indeed, this close engagement with terminology and classifications is the aim of most of the chapters. They analyse commonly used terms and test how these apply (or not) to their case study. This agenda is interesting and makes for a compelling read. Ulla Kypta's chapter is an excellent example. Her chapter on German merchants in the late medieval period questions what we mean by a small firm. She questions not only the categorisation of a firm's size but even the meaning of the term "firm«. The analysis of the organisational arrangements in Germany ranges from the more commonly discussed examples and also includes servants (diener, knechte) as well as factors (faktor, lieger). She establishes how far these concepts in Germany married up to what is thought of when one uses the English term rather than the German word. Kypta notes the terminological complexity in the works of those studying companies and argues that company size should not be categorised according to universal benchmarks, such as the number of partners, employees or turnover. Instead, she favours a definition where size is judged relatively, in the context of a particular market or sector.

Other chapters push this discussion exceptionally well. Anja Amend-Traut reveals the preferred legal structure for enterprises operating in the Hanseatic trading area in the early modern period. This is a particularly interesting chapter because it discusses law that is now defunct and no longer in use. This creates an additional layer of challenges for Amend-Traut, who has to consider a range of well known but disputed expressions to describe a legal system that has been lost. Nevertheless, early antecedents are important in understanding modern doctrines and principles of law. AmendTraut explores the historical roots of terms such as compagnia, compagnien and accommendatio, and their relationship to one another. She uses the suffix »-like« to denote where similarities between organisational forms began. This insightful chapter explores why merchants and traders would engage in a particular legal relationship when there were other choices in organisational form.

This collection thus provides interesting insights into the question of how we use terminology to describe arrangements or ideas for the analysis of periods when the concepts themselves did not exist. This language was not well developed or 
understood to carry those meanings just yet. These chapters show that it is not a case of forcing facts and language into conceptual frameworks or engaging in a form of ex post facto categorisation. There is a good deal of contextualisation involved in the unpacking of what these legal ideas meant when, where and to whom. Overall, this collection shows the value of discussing concepts explicitly. It creates some much-needed clarity, and this is perhaps the best way of establishing differences and similarities for comparative legal and historical research. The volume's contributions show the way that legal study, through its demand for precision in language and its definition and meaning, can inform business and economic history; it is a fruitful example of how legal history can be combined with business and economic history.

\section{Albrecht Cordes Zünfte und Wirtschaftswachstum*}

Seit vielen Jahren beschäftigt sich Sheilagh Ogilvie, kanadische Wirtschaftshistorikerin an der Universität Cambridge und Mitglied der British Academy, mit Gilden und Zünften ${ }^{\mathbf{1}}$ und ihrer wirtschaftlichen Bedeutung. Sie begann einst mit den württembergischen »Engelsaitwebern« (wohl von »English satin « - Hersteller wertvoller Tuche) in Calw und Wildberg im Nordschwarzwald im 17. Jahrhundert und hat seitdem den Fokus zeitlich wie räumlich immer weiter geöffnet. 2011 erschien ihr Buch über die Kaufmannsgilden (»Institutions and European Trade. Merchant Guilds 1000-1800«), und nun folgt unter der gleichen Leitfrage das Pendant auf der Ebene der Handwerkerzünfte: Haben Gilden und Zünfte zum Wirtschaftswachstum beigetragen? Ihre Antwort ist negativ. Von einem wirtschaftsliberalen Standpunkt aus charakterisiert Ogilvie die Zusammenschlüsse der Kaufleute und Handwerker als am Gemeinwohl kaum interessierte Vereinigungen, denen es vor allem um die Sicherung der Vorteile ihrer Mitglieder zum Nachteil der Konkurrenz, der Kunden und des technischen Fortschritts ging und die dazu hohe Eingangsbarrieren errichteten, nach besten Kräften mit den Regierungen der Länder und Städte kollaborierten und die Märkte manipulierten, indem sie die Lieferketten kontrollierten und die Preise hochhielten.

Das Buch über die Handwerker, um das es hier geht, ist eine Summe. Es handelt sich um ein monumentales Werk, das acht Jahrhunderte und halb Europa, mit einem Schwerpunkt in Mittelund Westeuropa in der Frühen Neuzeit, umspannt und auf nicht weniger als 17384 Einzeldaten beruht, welche die Autorin entweder in jahrzehntelangen Archivstudien selbst erhoben oder anderen großen quantitativ arbeitenden Fallstudien entnommen hat. Zentren ihrer eigenen Sammeltätigkeit sind vor allem Südwestdeutschland und Böhmen. In neun Kapiteln und einer Zusammenfassung beschäftigt sie sich mit dem Forschungsstand, der Beziehung der Zünfte zu den Regierungen, Zugangsbarrieren, Marktbeeinflussung und der Rolle von Frauen in den Zünften, weiter der Qualitätsregulierung, dem menschlichen Kapital und der Innovationskraft. Das letzte Kapitel

\footnotetext{
* Sheilagh Ogilvie, The European Guilds. An Economic Analysis, Princeton / Oxford: Princeton University Press 2019, XVI + 645 S., ISBN 978-0-691-13754-4

1 Zur Terminologie: "European Guilds« handelt von Handwerkszünften im Sinne von genossenschaftlichen Zusammenschlüssen von Personen, die ein und dasselbe
}

\author{
Handwerk betreiben (und sich darin \\ von Kaufmannsgilden unterschei- \\ den), unabhängig von der histori- \\ schen Selbstbezeichnung dieser Kor- \\ porationen, die von landschaftlichen \\ und lokalen Umständen abhing. \\ Es handelt sich also bei Ogilvies \\ "Guilds« und der Übersetzung \\ "Zünfte« nicht um Quellen-, sondern \\ um wissenschaftliche Ordnungsbe-
}

griffe. Nur am Rande sei erwähnt, dass viele Aufgaben und Institutionen wie Zunftmeister, Trinkstuben und Totengedenken nicht allein typisch für Zünfte und Gilden waren, sondern in den vielen vormodernen Korporationen, denen es nicht um den Betrieb eines gemeinsamen Handwerks ging, begegnen. 